\title{
Structural Analysis of Anxiety in Online Cooperative Learning
}

\author{
Hiroki Yoshida, Seiji Tani, Tomoko Uchida, Jitsuko Masui, and Akira Nakayama
}

\begin{abstract}
Previous studies suggest that learners' anxiety has negative effects on their behaviors, attitudes and achievements in online cooperative learning. Cooperative learning via the Internet requires learners to operate the learning system properly, and to cooperate with others effectively with the aim to accomplish a specific goal. In such a leaning situation, it is anticipated that learners might feel uneasy or fearful about using a computer and the Internet, and communicating with new acquaintances. However, few studies have focused on both of the aspects of learners' anxiety. This study purposed to identify learners' anxiety in online cooperative learning situations. As a result, 13 anxiety statements were identified as items for anxiety in online cooperative learning, and the 13 items were classified into three clusters: "computer anxiety", "online learning anxiety", and "communication anxiety".
\end{abstract}

Index Terms-Anxiety, cooperative learning, online learning, internet-based learning.

\section{INTRODUCTION}

The development of the knowledge society has brought about a major change in teaching and learning. Learning is not restricted to learning in the classroom of formal education institutions: it is a dynamic activity that occurs anywhere, anytime, and carried out by anybody. Learners can get information to build up their knowledge in various ways including the Internet. The teacher's role is changing from that of an authority that distributes or transmits knowledge based on a specific subject [1], to a facilitator who enhances learners' cooperation, a tutor who motivates learners to learn continuously and eagerly, and a manager who coordinates and monitors the learning process. Salamon [2] uses a metaphor regarding the role of the teacher in the knowledge society: a designer, a tourist guide, and the conductor of an orchestra.

In order to cope with the structural change of the society, school systems are required to recognize the significance of learning objectives such as social competence, critical thinking, knowledge sharing, and cooperation techniques [3]. Therefore, learning methods that require active interaction among the learners such as cooperative learning are being implemented in schools and universities. Cooperative learning can be defined as "a set of processes which help people interact together in order to accomplish a specific goal or develop an end product which is usually content specific"

Manuscript received March 1, 2013; revised July 2, 2013. This work was supported by JSPS KAKENHI Grant Number 23520749.

Hiroki Yoshida, Seiji Tani, and Jitsuko Masui are with Tokoha University, Shizuoka, Japan (e-mail: h-yoshida@sz.tokoha-u.ac.jp)

Tomoko Uchida is with Jeju National University, Jeju, Korea.

Akira Nakayama is with Ehime University, Ehime, Japan.
[4]. Effective cooperative learning requires 1) positive interdependence, 2) individual accountability, 3) promotive interaction, 4) social skills, and 5) group processing [5], [6]. When these elements are well structured into the learning process, cooperative learning leads to increase not only learners' academic performance, but also their participation, responsibility [7], basic needs, and intrinsic motivation [8].

Using synchronous and asynchronous computer-mediated communication tools, cooperative learning is now possible online. Internet-based cooperative learning enables learners who are far away from each other collaborate/cooperate and achieve a common goal. Furthermore, Bliss and Lawrence [9], [10] have reported that computer-mediated cooperative learning resulted in significant increase of student participation, frequency of interaction, and the quality of students' conversation.

However, there are some problem areas that have to be considered in the implementation of online cooperative learning. One of the major issues is the learners' anxiety in learning online [11]-[16]. Simonson et al. defined computer anxiety as "fear or apprehension felt by individuals when they used computers, or when they considered the possibility of computer utilization" [16]. Saadé and Kira reported that about fifty percent of adults including university students have some sort of computer anxiety [11]. Computer anxiety is known as a strong determinant of perceived ease of use toward a computer-mediated learning system [11]-[14].

Attempts have been made to identify the contents and structure of computer anxiety, internet anxiety, and e-learning anxiety. Heissen et al. developed a "Computer Anxiety Rating Scale (CARS)" consisted of 19 items that measure users' computer anxiety on a five-point Likert scale [17]. Havelka and Beasley conducted a factor analysis and revealed four distinct factors in the CARS: namely, general anxiety toward computer usage, confidence in learning ability, motivation to learn, and power or control of usage [18]. The difficulty of applying CARS in an Internet-based cooperative learning situation is that CARS only focuses on anxiety in operating a computer-meditated system and/or learning how to operate the system.

Internet anxiety is closely related to computer anxiety but is considered a different concept [19]. Presno identified four factors of Internet anxiety: Internet terminology anxiety, net search anxiety, Internet time delay anxiety, and general fear of Internet failure [20]. Tsai developed an "Online Learning Strategies Scale (OLSS)" consisted of 20 items including 3 items that measure Internet anxiety [21]. OLSS not only focuses on anxiety in operating the system, but also anxiety about the learning process and achievements. However, OLSS mainly targets learners who take e-learning courses 
that require individual, self-regulated learning, and therefore, does not measure learners' anxiety to communicate and cooperate with other learners via the Internet.

Different from traditional "e-learning", online cooperative learning requires learners to communicate and work together cooperatively in order to accomplish a certain goal. It is anticipated that learners in Internet-based cooperative learning situations might have social anxiety in communicating and/or cooperatively working with other learners. In fact, recent studies point out the effects of social anxiety on computer-mediated communication (CMC), leading to users' attitude toward use of the systems and their usage behavior [22]-[25].

Given the situation, it is needed to identify what learners fear or feel apprehensive when they learn cooperatively online. Therefore, this study aims to identify learners' anxiety in Internet-based cooperative learning.

\section{PURPOSE}

The purpose of this study is to identify learners' anxiety in online cooperative learning. The research questions to be addressed in this paper are: 1) What are Japanese university students uneasy, fearful or worried about when they learn cooperatively with foreigners via the Internet? 2) What is the structure of learners' anxiety for online cooperative learning?

\section{Methodology}

A questionnaire survey was conducted from October 15th to 26th, 2012, with the purpose of identifying learners' anxiety in online cooperative learning, and the structure of the learners' anxiety.

\section{A. Participants}

The participants were 31 Japanese first-year university students who participated in Korean language classes. The participants were to experience project based cooperative learning via the Internet with Korean university students who study in Jeju, Korea. During the Internet-based cooperative learning session, participants were to work in a group of five students: two Japanese students and three Korean students.

\section{B. Questionnaire}

A self-report questionnaire sheet, which was a written form of free-response style, was used to identify learners' anxiety for cooperative learning via the Internet. Participants were asked what they are uneasy, fearful or worried about when they learn cooperatively via the Internet.

\section{Procedure}

The participants first got lectured about the learning objectives and tasks of the Internet-based cooperative learning activity they were to experience with university students in Korea. Then, participants were demonstrated and taught how to use the Learning Management System (LMS) they were to use during the cooperative learning session. After that, participants answered to the questionnaire on anxiety in online cooperative learning.

\section{RESUlTS}

All of the participants completed a questionnaire survey that was conducted before the online learning session. This means that the response rate was 100.00 percent. Hereinafter, the results of the 31 answers will be introduced.

\section{A. Participants' Profile}

Table I shows the breakdown of participants by gender, experience of communicating with Koreans, and possession of a personal computer. The reason for the large proportion of the women is that all of the participants were language learners who major in foreign studies. Most of the participants mentioned that they have never communicated with Korean people before. Personal computer ownership was 48.39 percent which is relatively low compared with the penetration rate of computers in Japan which is 77.3 percent as of March, 2012 [26].

TABLE I: PROFILE OF PARTICIPANTS

\begin{tabular}{llrc}
\hline \multicolumn{2}{c}{ Profile of participants } & Frequency & $\%$ \\
\hline \hline \multirow{2}{*}{ Gender } & Male & 6 & $19.35 \%$ \\
& Female & 25 & $80.65 \%$ \\
\hline \multirow{2}{*}{$\begin{array}{l}\text { Experience of communicating } \\
\text { with Koreans }\end{array}$} & Total & 31 & \\
\hline \multirow{2}{*}{$\begin{array}{l}\text { Yossession of a personal } \\
\text { computer }\end{array}$} & No & 8 & $25.81 \%$ \\
\hline & Total & 23 & $74.19 \%$ \\
\hline \hline
\end{tabular}

\section{B. Anxiety in Online Cooperative Learning}

The KJ method was used to group the participants' anxiety statements with similar contents or characteristics together. In order to achieve validity and reliability of the classification and grouping of the anxiety, the procedure was helped by a researcher majoring in language education and a researcher majoring in educational psychology. As a result, 17 anxiety statements were determined for the anxiety in online cooperative learning (see Table II).

Results of the survey reveal that more than half of the participants were fearful of communicating with new people, making mistakes that they cannot correct, hitting the wrong key or clicking the wrong hyperlink, working in group, gathering information via the Internet, communicating with others, computer-related terms, telling their feelings or ideas, their accomplishment, and using computers.

Rationale for the apparent high anxiety for communicating and cooperating in group with others is because most of the participants have never communicated with a Korean before the Internet-based cooperative learning session.

It is presumed that the high anxiety for using computers and the Internet for learning comes from the relatively low possession rate of personal computers.

Among the 17 anxiety statments decided in this study, 9 statements are related with anxiety items described in the previous studies. Item \#2 (I fear of making mistakes I cannot correct.), \#3 (I fear of hitting the wrong key or clicking the wrong hyperlink.), \#10 (I feel apprehensive about using 
computers.), and \#11 (I am worried if I can properly operate the system.) are anxiety items that are included in Heinssen et al.’s CARS [17]. Item \#5 (I am worried if I can gather needed information.), \#7 (I am worried if I can understand computerrelated terms.), and \#13 (I feel apprehensive about learning via the Internet.) are statements related with Internet anxiety factors noted by Presno [20]. Item \#9 (I am worried if I can accomplish the learning objective.), and \#12 (I am worried about my achievements in online cooperative learning.) are statements that are similar to the Internet anxiety items presented in Tsai's OLSS [21].

The rest of the anxiety items cannot be found in previous computer anxiety scales and/or Internet anxiety scales. However, item \#1 (I fear of communicating with a new acquaintance.), \#4 (I am tense and nervous while participating in group discussions.), and \#8 (I am worried if I can tell others what I want to say.) are statements that are suggested by McCroskey et al. in the "Personal Report of Communication Apprehension (PRCA-24)" which is a scale that is widely used by educators to predict learners' anxiety about communication with other people [27].

TABLE II: ANXIETY IN ONLINE COOPERATIVE LEARNING

\begin{tabular}{|c|c|c|}
\hline Items & Frequency & $\%$ \\
\hline $\begin{array}{l}\text { I fear of communicating with a new } \\
\text { acquaintance. }\end{array}$ & 20 & $64.52 \%$ \\
\hline 2. I fear of making mistakes I cannot correct. & 19 & $61.29 \%$ \\
\hline $\begin{array}{l}\text { I fear of hitting the wrong key or clicking the } \\
\text { wrong hyperlink. }\end{array}$ & 18 & $58.06 \%$ \\
\hline $\begin{array}{l}\text { I am tense and nervous while participating in } \\
\text { group discussions. }\end{array}$ & 18 & $58.06 \%$ \\
\hline $\begin{array}{l}\text { I am worried if I can gather needed } \\
\text { information. }\end{array}$ & 18 & $58.06 \%$ \\
\hline $\begin{array}{l}\text { I am worried if I can communicate effectively } \\
\text { with other learners. }\end{array}$ & 18 & $58.06 \%$ \\
\hline $\begin{array}{l}\text { I am worried if I can understand } \\
\text { computer-related terms. }\end{array}$ & 17 & $54.84 \%$ \\
\hline $\begin{array}{l}\text { 8. I am worried if I can tell others what I want to } \\
\text { say. }\end{array}$ & 17 & $54.84 \%$ \\
\hline $\begin{array}{l}\text { I am worried if I can accomplish the learning } \\
\text { objective. }\end{array}$ & 17 & $54.84 \%$ \\
\hline 10. I feel apprehensive about using computers. & 16 & $51.61 \%$ \\
\hline $\begin{array}{l}\text { I1. am worried if I can properly operate the } \\
\text { system. }\end{array}$ & 15 & $48.39 \%$ \\
\hline $\begin{array}{l}\text { I am worried about my achievements in online } \\
\text { cooperative learning. }\end{array}$ & 13 & $41.94 \%$ \\
\hline $\begin{array}{l}\text { I feel apprehensive about learning via the } \\
\text { Internet. }\end{array}$ & 12 & $38.71 \%$ \\
\hline $\begin{array}{l}\text { I am worried if I can understand what other } \\
\text { learners are saying. }\end{array}$ & 3 & $9.68 \%$ \\
\hline $\begin{array}{l}\text { I am worried if I can understand the } \\
\text { instructions of operating the system. }\end{array}$ & 2 & $6.45 \%$ \\
\hline 16. I fear of invading other learners' privacy. & 1 & $3.23 \%$ \\
\hline $\begin{array}{l}\text { I fear not knowing when it is appropriate to } \\
\text { make comments. }\end{array}$ & 1 & $3.23 \%$ \\
\hline
\end{tabular}

\section{Statistical Analysis}

Participants' responses were classified using Hayashi's quantification method type III. Item \# 14 (I am worried if I can understand what other learners are saying.), \#15 (I am worried if I can understand the instructions of operating the system.), \#16 (I fear of invading other learners' privacy.), and \#17 (I fear not knowing when it is appropriate to make comments.) were deleted from further analysis because few participants commented that they had these three sort of fear of apprehension, and if the items were included in the statistical analysis, they put too much category weight to all of the axes. Thus, 13 anxiety items were selected to be analyzed.

Table III shows the normalized category weights given to participants' anxiety for learning cooperatively online with foreigners. According to the tendency of the decrease of the eigenvalue (first axis: 0.3028 , second axis: 0.2872 , third axis: 0.0545 , fourth axis: 0.0538 ) and the cumulative proportion (first axis: 35.24 percent, second axis: 68.67 percent, third axis: 75.02 percent, forth axis: 81.27 percent), two axes were determined and interpreted.

TABLE III: NORMALIZED CATEGORY WEIGHTS TO PARTICIPANTS' ANXIETY IN ONLINE COOPERATIVE LEARNING

\begin{tabular}{|c|c|c|}
\hline Category & Axis 1 & Axis2 \\
\hline $\begin{array}{l}\text { I1. I am worried if I can properly operate the } \\
\text { system. }\end{array}$ & 1.3046 & -0.7750 \\
\hline 10. I feel apprehensive about using computers. & 1.1889 & -0.6773 \\
\hline $\begin{array}{l}\text { 7. am worried if I can understand } \\
\text { computer-related terms. }\end{array}$ & 1.0441 & -0.5734 \\
\hline $\begin{array}{l}\text { 3. I fear of hitting the wrong key or clicking the } \\
\text { wrong hyperlink. }\end{array}$ & 0.9211 & -0.6988 \\
\hline 2. I fear of making mistakes I cannot correct. & 0.7977 & -0.3966 \\
\hline $\begin{array}{l}\text { 13. I feel apprehensive about learning via the } \\
\text { Internet. }\end{array}$ & 0.2431 & 1.2722 \\
\hline 5. I am worried if I can gather needed information. & 0.0837 & 1.8486 \\
\hline $\begin{array}{l}\text { 12. I am worried about my achievements in online } \\
\text { cooperative learning. }\end{array}$ & 0.0674 & 1.7588 \\
\hline $\begin{array}{l}\text { I am worried if I can accomplish the learning } \\
\text { objective. }\end{array}$ & -0.2509 & 1.6139 \\
\hline $\begin{array}{l}\text { 8. I am worried if I can tell others what I want to } \\
\text { say. }\end{array}$ & -0.9640 & -0.2976 \\
\hline $\begin{array}{l}\text { 4. I am tense and nervous while participating in } \\
\text { group discussions. }\end{array}$ & -0.9663 & -0.4748 \\
\hline $\begin{array}{l}\text { I fear of communicating with a new } \\
\text { acquaintance. }\end{array}$ & -1.0545 & -0.5802 \\
\hline $\begin{array}{l}\text { 6. I am worried if I can communicate effectively } \\
\text { with other learners. }\end{array}$ & -1.8882 & -0.8758 \\
\hline
\end{tabular}

Fig. 1 shows a two-dimensional scatter graph of the category scores of each item.

Results of the statistical analysis indicate that the participants' anxiety in online cooperative learning can be classified into three clusters.

The first cluster consists of five items: item \#2 (I fear of making mistakes I cannot correct.), \#3 (I fear of hitting the wrong key or clicking the wrong hyperlink.), \#7 (I am worried if I can understand computer-related terms.), \#10 (I feel apprehensive about using computers.), and \#11 (I am worried if I can properly operate the system.), that had high category scores on the first correlation axis and comparatively low scores on the second axis. As all of the four items are related with the fear or apprehension in the utilization of computer- related devices, the first cluster was given the name "computer anxiety".

The second cluster includes four items: \#5 (I am worried if I can gather needed information.), \#9 (I am worried if I can accomplish the learning objective.), \#12 (I am worried about my achievements in online cooperative learning.), and \#13 (I feel apprehensive about learning via the Internet.), that had high category scores on the second correlation axis. All of the four items are related with the fear or apprehension in learning online. Therefore, the second cluster was named "online learning anxiety". 
The third cluster also consists of four items: \#1 (I fear of communicating with a new acquaintance.), \#4 (I am tense and nervous while participating in group discussions.), \#6 (I am worried if I can communicate effectively with other learners.), and \#8 (I am worried if I can tell others what I want to say.), that had relatively low category scores on both of the correlation axes. All of the four items are related with the fear or apprehension in communicating and/or cooperating online with other learners, and therefore was given the name "communication anxiety".

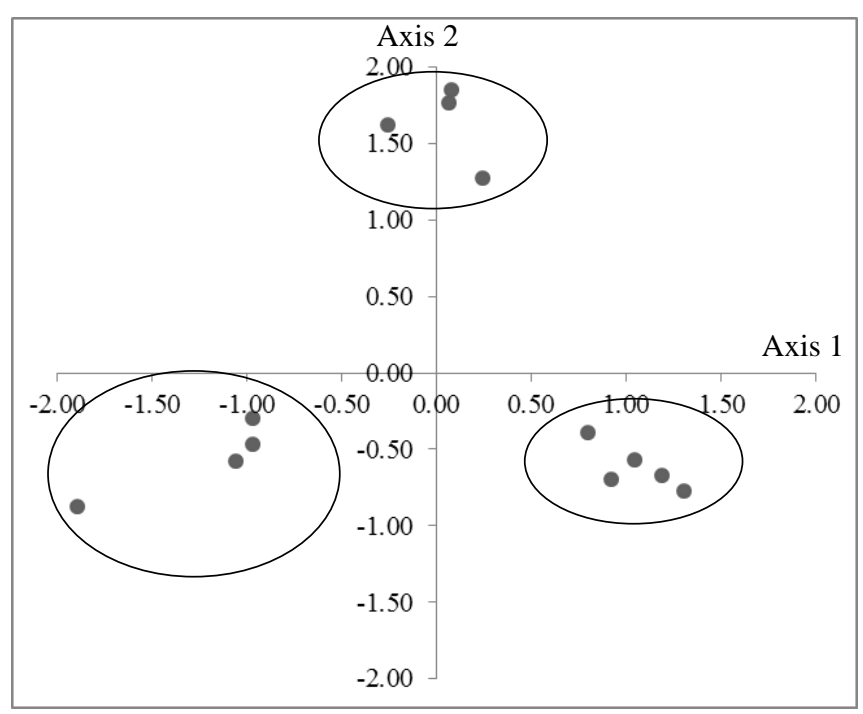

Fig. 1. Two-dimensional plot graph of participants' anxiety for online cooperative learning.

\section{Discussions}

The purpose of the study was to identify Japanese university students' anxiety in online cooperative learning. In order to gather learners' anxiety statements on online cooperative learning, an open-ended question was used.

Regarding the first research question "What are Japanese university students uneasy, fearful or worried about when they learn cooperatively with foreigners via the Internet?", results of the questionnaire survey show that Japanese university students majoring in foreign studies are highly anxious about communicating with new acquaintances, making mistakes that they cannot correct, hitting the wrong key or clicking the wrong hyperlink, working in group, gathering information via the Internet, communicating with others, computer-related terms, telling their feelings or ideas, their accomplishment, and using computers.

With regard to the second research question "What is the structure of learners' anxiety for Internet-based cooperative learning?", statistical analysis using Hayashi's quantification method type III revealed that the participants' anxiety for online cooperative learning can be classified into three groups, namely, "computer anxiety", "online learning anxiety", and "communication anxiety".

\section{CONCLUSION}

The results of the study suggest that learners' anxiety in Internet-based cooperative learning consists of not only technology-related anxiety but also social anxiety based on the fear or apprehension to communicate and/or collaborate with others. As the Internet is a powerful and global medium for communication as well as a medium of information, and Internet-based cooperative learning requires interaction and/or communication among the learners, it is important to focus on learners' social/communication anxiety to ensure the quality of online cooperative learning.

Since the participants of this study were Japanese university students who major in foreign studies and were mainly women who are not highly ICT literate, using another sample from elsewhere is required for future generalization of the items.

Given the findings of this study, it is necessary to develop an online cooperative learning scale and examine the content validity, structural validity and reliability of the scale. Thus, it would be possible to identify what kind of learners have what kind of anxiety, leading to what kind of learning behavior/ strategy and learning outcome.

The goal of this study is not just to clarify learners' anxiety in online cooperative learning situations. The findings of this study must contribute to suggest instructors how to reduce learners' anxiety in Internet-based cooperative learning activities. Previous studies suggest the significance of the role of online facilitators in Internet-based cooperative learning [28]-[33]. Therefore, it is expected to specify the roles and responsibilities of online facilitators with the aim of helping learners who take Internet-based cooperative learning courses reduce their anxiety in learning online cooperatively, and learn effectively.

\section{REFERENCES}

[1] J. M. Moreno. Learning to Teach in the Knowledge Society: Final Report, World Band. [Online]. Available: http://siteresources.worldbank.org/EDUCATION/Resources/2782001126210664195/1636971-1126210694253/Learning_Teach_Knowled ge_Society.pdf

[2] G. Salomon, "The changing role of the teacher: from information transmitter to orchestrator of learning," in F. E. A Oser, (Ed), Effective and Responsible Teaching: The new synthesis, pp. 35-49. New York: Jossey-Bass, 1992

[3] Y. Punie, D. Zinnbauer, and M. Cabrera, "A review of the impact of ICT on learning," European Commission, Joint Research Centre, Institute for Prospective Technological Studies, 2008.

[4] T. Panitz. A Definition of Collaborative vs Cooperative Learning. [Online]. Available: http://www.londonmet.ac.uk/deliberations/collaborative-learning/pani tz-paper.cfm

[5] R. T. Johnson and D. W. Johnson, "An overview of cooperative learning," in J. Thousand, A. Villa, and A. Nevin, Eds, Creativity and Collaborative Learning, 1994, pp. 31-44. Baltimore: P. H. Brookes Press.

[6] D. W. Johnson and R. T. Johnson, "Making cooperative learning work," Theory into Practice, vol. 38, no. 2, pp. 67-73, 1999.

[7] W. Assinder, "Peer teaching, peer learning: One model," ELT Journal, vol. 45 , pp. 218-229, 1991.

[8] M. Hanze and R. Berger, "Cooperative learning, motivational effects, and student characteristics: An experimental study comparing cooperative learning and direct instruction in 12th grand physics classes," Learning and Instruction, vol. 17, pp. 29-41, 2007.

[9] C. A. Bliss and C. Lawrence, "From posts to patterns: A metric to characterize discussion board activity in online courses," Journal of Asynchronous Learning Networks, vol. 13, no. 2, pp. 15-32, 2009.

[10] C. A. Bliss and B. Lawrence, "Is the whole greater than the sum of its parts? A comparison of small group and whole class discussion board activity in online courses," Journal of Asynchronous Learning Networks, vol. 13, no. 4, pp. 25-39, 2009.

[11] R. G. Saadé, and D. Kira, "Computer anxiety in E-learning: The effect of computer self-efficacy," Journal of Information Technology Education, vol. 8, pp. 177-191, 2009. 
[12] A. R. Alenezi, A. M. Abdul Karim, and A. Veloo, "An empirical investigation into the role of enjoyment, computer anxiety, computer self-efficacy and internet experience in influencing the students' intention to use e-learning: A case study from Saudi Arabian governmental universities," The Turkish Online Journal of Educational Technology, vol. 9, no. 4, 2010.

[13] N. Mohamed and N. S. Abdul Karim, "Open source e-learning anxiety, self-efficacy and acceptance-A partial least square approach,' International Journal of Mathematics and Computers in Simulation, vol. 6, no. 4, pp. 361-368, 2012

[14] V. Venkatesh, "Determinants of perceived ease of use: integrated control, intrinsic motivation, and emotion into the technology acceptance model," Information Systems Research, vol. 11, no. 4, pp. 342-365, 2000.

[15] H. K. Sam, A. E. A. Othman, and Z. S Nordin, "Computer self-efficacy, computer anxiety, and attitudes toward the internet: a study among undergraduates in unimas," Educational Technology \& Society, vol. 8 , no. 4, pp. 205-219, 2005.

[16] M. R. Simonson, A. Matt, and M. M. Maurer, "Development of a standardized test of computer literacy and a computer anxiety index," Journal of Educational Computing Research, vol. 3, no. 2, pp. 231-247, 1987.

[17] R. K. Heinssen, C. R. Glass, and L. A. Knight, “Assessing computer anxiety: Development and validation of the computer anxiety rating scale," Computers in Human Behavior, vol. 3, pp. 49-59, 1987.

[18] D. Havelka and F. Beasley, "An examination of the factor structure of the computer anxiety rating scale," Journal of College Teaching \& Learning, vol. 1, no. 4, pp.51-56, 2004.

[19] J. B. Thatcher, M. L. Loughry, J. Lim, and D. H. McKnight, "Internet anxiety: An empirical study of the effects of personality, beliefs, and social support," Information \& Management, vol. 44, pp. 353-363, 2007.

[20] C. Presno, "Taking the byte out of Internet anxiety: instructional techniques that reduce computer/Internet anxiety in the classroom,' Journal of Educational Computing Research, vol. 18, no. 2, pp. 147-161, 1998

[21] M. J. Tsai, The Model of Strategic e-Learning: Understanding and evaluating student e-learning from metacognitive perspectives, Educational Technology \& Society, vol. 12, no. 1, pp. 34-48, 2009.

[22] S. A. Brown, R. M. Fuller, and C. Vician, "Who's afraid of the virtual world? Anxiety and computer-mediated communication," Journal of the Association for Information Systems, vol. 15, no. 2, pp.79-107, 2004.

[23] Y. Nishimura, "An examination of state communication anxiety: communication medium, and trait social anxiety," The Japanese Journal of Personality, vol. 13, no. 2, pp.183-196, 2005.
[24] H. M. Satar, and N. Ozdener, "The effects of Synchronous CMC on speaking proficiency and anxiety: Text Versus Voice Chat," The Modern Language Journal, vol. 92, no. 4, pp.595-613, 2008.

[25] L. Rice, and P. M. Markey, "The role of extraversion and neuroticism in influencing anxiety following computer-mediated interactions," Personality and Individual Differences, 46, pp.35-39, 2009.

[26] Economic and Social Research Institute, Cabinet Office, Government of Japan. "Monthly consumer confidence survey covering all of Japan March 2012," 2012.

[27] J. C. McCroskey, M. J. Beatty, P. Kearney, and T. G. Plax, "The content Validity of the PRCA-24 as a measure of communication apprehension across communication contents," Communication Quarterly, vol. 33, no. 3, pp. 165-173, 1985.

[28] M. Coghlan. (2001). E-moderation - managing a new language? Net Working 2001 Conference. [Online]. Available: http://users.chariot.net.au/,michaelc/nw2001/emod_newlang.htm,

[29] G. Kemshal-Bell. The on-line teacher. Final report prepared for the Project Steering Committee of the VET Teacher and On-line Learning Project, ITAM, ESD, TAFENSW. [Online]. Available: http://cyberteacher.onestop.net/final per cent20report.pdf.

[30] M. McVay-Lynch, The On-line Educator-A Guide to Creating the Virtual Classroom, London: Routledge, 2002

[31] Australian Flexible Learning Network (AFLN). Effective on-line facilitation. Australian Flexible Learning Quick Guide Series. [Online]. Available: http://flexiblelearning.net.au

[32] G. Packham, P. Jones, C. Miller, and B. Thomas. (2004). Perceptions of Effective E-moderation: A Tutors Viewpoint. The Networked Learning $\begin{array}{ll}\text { Conference. } & \text { [Online]. Available: }\end{array}$ http://www.networkedlearningconference.org.uk/past/nlc2004/procee dings/individual_papers/packham_et_al.htm, 2004.

[33] G. Packham, P. Jones, B. Thomas, and C. Miller, "Student and tutor perspectives of on-line moderation," Education + Training, vol. 48, no. 4, pp.241-251, 2006.

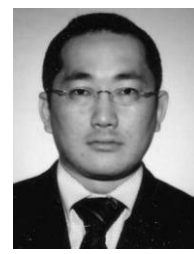

H. Yoshida was born in Nara, Japan in 1973. He received the MEd in Educational technology from International Christian University, Japan in 1999. He is currently an associate professor at Tokoha University in Shizuoka, Japan. His research interests include online learning, cooperative learning, hypermedia education, audio-visual education, and teacher education. 